\title{
PENGARUH HUMAN CAPITAL TERHADAP ECONOMIC VALUE ADDED PADA SEKTOR UMKM DI PROVINSI BALI
}

\author{
Komang Agus Rudi Indra Laksmana ${ }^{1}$, I Ketut Merta ${ }^{2}$ \\ 1Universitas Mahendradatta, Denpasar, Indonesia. email, Indonesia \\ Email: ilaksmana70@gmail.com \\ 2Universitas Mahendradtta, Denpasar, Indonesia
}

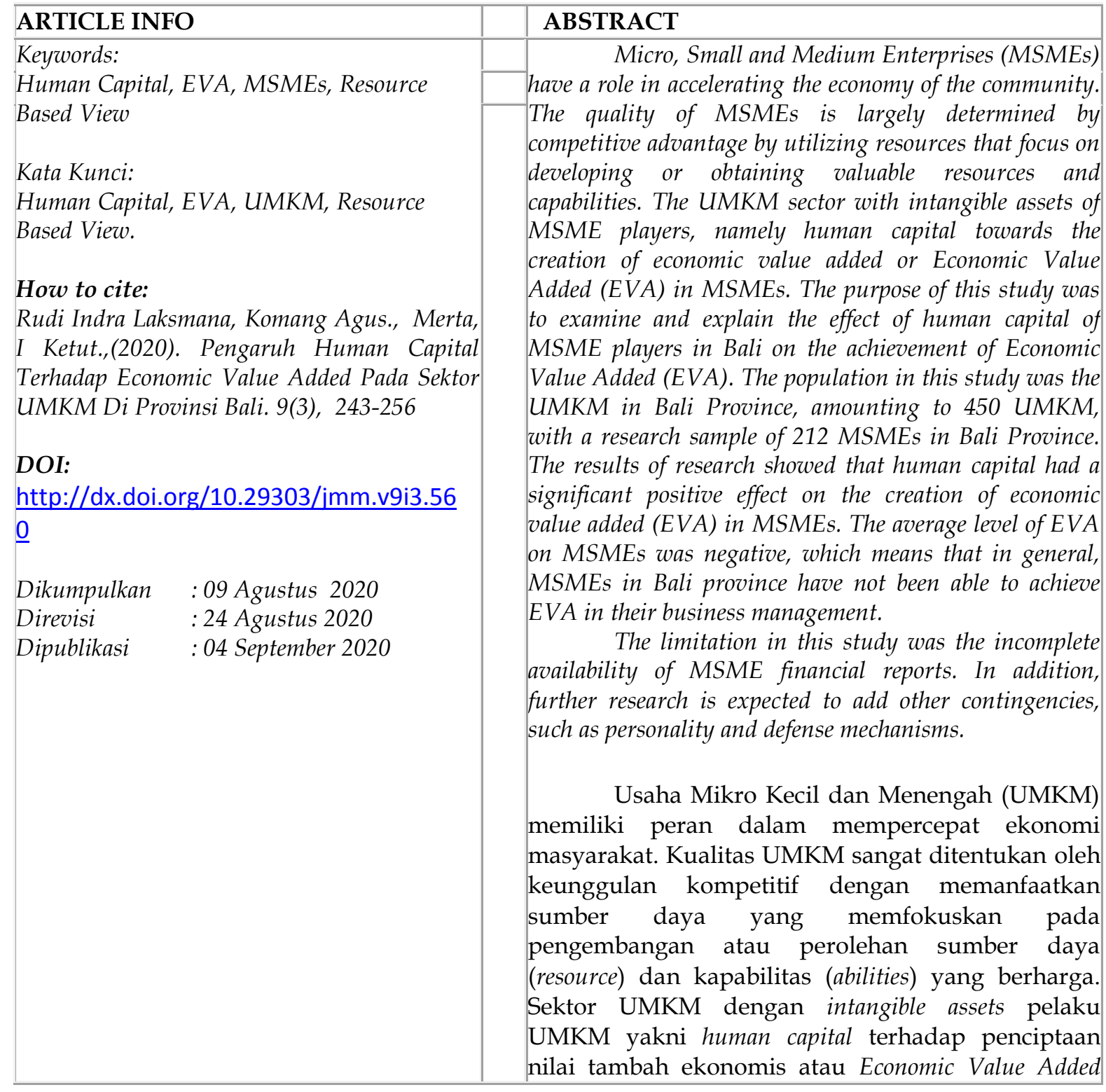




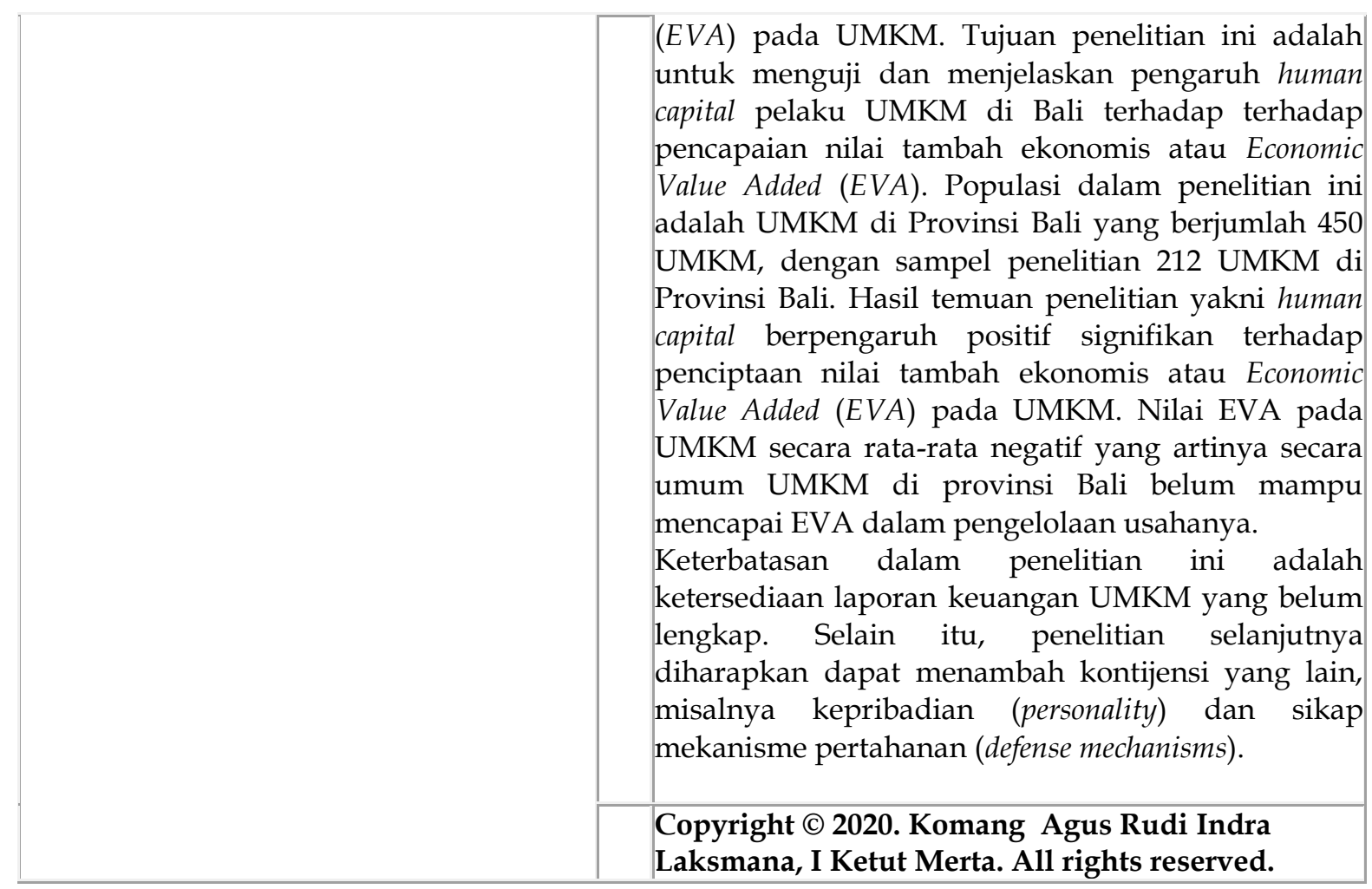

\section{PENDAHULUAN}

Indonesia saat ini memiliki 59,2 juta sektor Usaha Mikro, Kecil dan Menengah (UMKM) atau 25\% dari total penduduk Indonesia sebanyak 250 juta yang berkontribusi terhadap PDB Nasional. Penyerapan tenaga kerja sebesar 97,27\% dari total tenaga kerja di Indonesia dan sumbangan PDB sebesar 56,22\% (Badan Pusat Statistik, 2018). Potensi UMKM di Indonesia sangat besar sehingga lintas Kementerian membuat kebijakan dalam mendukung perkembangan sektor ini melalui pemberian kredit lunak, pelatihan dan pendidikan kepada pelaku UMKM serta bantuan modal peralatan produksi. Berbagai potensi tersebut juga ditemukan beberapa kelemahan berdasarkan hasil penelitian dari Kementerian Negara KUKM dan BPS tahun 2003 bahwa terdapat permasalahan dalam bidang permodalan, pemasaran, bahan baku, ketenagakerjaan dan distribusi tranportasi.

Provinsi Bali merupakan salah satu provinsi di Indonesia yang memiliki jumlah UMKM terbesar pada tahun 2018 terdapat 265 ribu UMKM yang didominasi oleh kerajinan souvenir, aneka jenis makana khas Bali dan busana seperti kain endek, batik hingga bahan kain kebaya. UMKM di Bali saat ini hanya berfokus pada aspek pemasaran namun tidak fokus pada pengelolaan keuangan dan pembiayaan, sehingga program peningkatan akses pembiayaan bagi UMKM di provinsi Bali menjadi usulan program prioritas kegiatan tahun 2019. Selanjutnya, kondisi ini juga diperparah dengan ketidakmampuan UMKM di Bali dalam mengurus ijin usaha serta menyusun laporan keuangan sehingga tidak mampu memenuhi administrasi dalam memanfaatkan fasilitas kredit lunak dari pemerintah (Paparan Kepala Diskop dan UKM Provinsi Bali, 2018).

Kualitas UMKM sangat ditentukan oleh keunggulan kompetitif dengan memanfaatkan sumber daya yang memfokuskan pada pengembangan atau perolehan sumber daya (resource) dan kapabilitas (abilities) yang berharga. Kombinasi unsur antara aset real sepeti sumber daya financial dan aset yang tidak terlihat (intangible asset) salah satunya pengetahuan dan pengalaman dapat diintegrasikan dalam mencapai tujuan yang 
diinginkan dikenal dengan konsep Resource Based View / RBV (Barney, 1991). RBV menjelaskan bagaimana usaha kecil mencapai daya saing untuk memperoleh keuntungan dan mencapai keunggulan kompetitif disaat mampu menciptakan nilai tambah dengan mengeksploitasi sumber daya untuk menghasilkan keunggulan kompetitif (Shafeey and Trott, 2014; Barney and Hesterly, 2012).

Modal Intelektual/Intelectual Capital (IC) menjadi bagian penting bagi perusahaan. IC terkait erat dengan RBV karena dianggap sebagai sumber potensial untuk keunggulan kompetitif bagi perusahaan. Komponen dari IC adalah Human Capital (HC), yang diakui oleh beberapa peneliti sebagai sumber daya tak berwujud (intangible asset) yang paling penting (Johansson, 2015). HC adalah kekuatan yang memandu dua komponen lainnya dari IC, yaitu, modal relasional dan modal sosial. Penciptaan nilai perusahaan dapat dilakukan dengan membangun keputusan investasi yang lebih baik, menggunakan struktur pembiayaan yang tepat atau menerapkan kebijakan investasi yang optimal. Ketika suatu perusahaan tidak dapat menghasilkan nilai tambah ekonomi (Economic Value Added) tidak menarik bagi investor, dan berisiko untuk tidak bertahan (Dillon and Owers, 1997).

Banyak penelitian telah dilakukan untuk mengkaji dampak efisiensi Human Capital (menggunakan model VAIC) dan kinerja perusahaan di negara maju (Ozkan et al., 2017; Sardo and Serrasqueiro, 2017). Selain itu, dalam beberapa tahun terakhir juga telah dilakukan banyak studi empiris mengenai ekonomi Asia (Al-Musali and Ismail, 2014; Mondal and Ghosh, 2012; Poh et al., 2018; Tran and Vo, 2018). Indeks modal manusia di Vietnam adalah yang tertinggi di antara negara-negara berpenghasilan menengah, namun, ada perbedaan antara kelompok etnis dan sektor. Oleh karena itu, diperlukan peningkatan keterampilan tenaga kerja untuk meningkatkan produktivitas. Selain itu, keahlian yang relevan dengan industri Vietnam untuk mahasiswa pascasarjana berada di peringkat rendah dalam laporan Indeks Daya Saing Global 2018. Peringkat rendah ini mencerminkan kurangnya nilai tambah per karyawan dalam kinerja Vietnam dibandingkan dengan negara lain (Bank Dunia, 2019). Pada saat yang sama, pemerintah Vietnam telah mengeluarkan serangkaian pedoman dan kebijakan yang bertujuan untuk meningkatkan produktivitas tenaga kerja dan mendukung pengembangan sumber daya manusia bagi perusahaan. Hoang, et al., (2018) melakukan survei terhadap 319 perusahaan teknologi informasi dan komunikasi Vietnam memperoleh hasil bahwa terdapat pengaruh positif dan signifikan modal intelektual (termasuk modal manusia, modal sosial, dan modal organisasi) terhadap kinerja perusahaan.

Penelitian ini bertujuan untuk melakukan uji pengaruh human capital terhadap penciptaan nilai tambah (economic value added) pada sektor UMKM. Pada penelitian ini akan berbeda dengan penelitian terdahulu, sebab perhitungan EVA akan digunakan pada sektor UMKM melalui pendekatan konsep Hudson, et al (2001). Selanjutnya, dilakukan indentifikasi hubungan diantara RBV dan EVA dengan menggunakan kutipan data laporan keuangan tahunan untuk perhitungan EVA.

\section{TINJAUAN PUSTAKA}

\subsection{Economic Value Added (EVA) pada Sektor UMKM}

Economic Value Added (EVA) dapat berfungsi dengan baik pada sektor UMKM, Garengo et al., (2005) mengusulkan bahwa harus memungkinkan manajer untuk mengidentifikasi tindakan yang mungkin untuk meningkatkan kinerja perusahaan dan menghilangkan inefisiensi. Kausalitas harus ditetapkan antara hasil dan faktor penentu kinerja UMKM, terutama untuk menilai keputusan masa lalu dan tindakan, tetapi juga untuk mengidentifikasi potensi perbaikan pada praktik bisnis perusahaan atau 
penggunaan sumber daya. UKM dapat menggunakan komponen keuangan dari EVA, yang tersedia langsung dari informasi akuntansi UMKM, digabungkan dengan kegiatan organisasi yang mempengaruhi UMKM, untuk mengidentifikasi bidang di mana UMKM dapat menciptakan nilai. Kegiatan-kegiatan ini disebut sebagai praktik bisnis, yang didefinisikan sebagai "Serangkaian operasi nyata yang dapat diamati yang dilakukan oleh karyawan perusahaan" (Boselie et al., 2005). Secara rinci konsep EVA dalam sektor UMKM digambarkan sebagai Performance Measurement and Management System (PMMS) yang memperhitungkan kedua aspek kinerja yakni kinerja kuantitatif dan kualitatif (Hudson, et al, 2001).

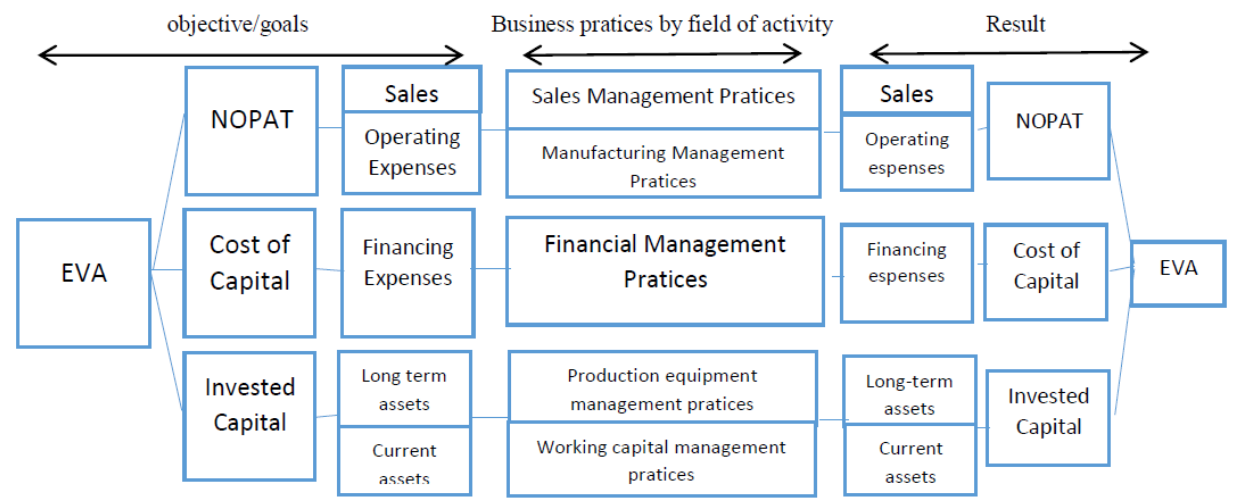

Gambar 1. Alat Pengukuran Kinerja Manajemen EVA (Hudson et al., 2001)

Rincian EVA dan koneksi dengan berbagai praktik bisnis ditunjukkan pada Gambar 1 menggambarkan bagaimana PMMS yang memperhitungkan kedua aspek kinerja kuantitatif dan kualitatif, seperti yang direkomendasikan oleh Hudson, et al (2001). Ini termasuk praktik manajemen penjualan yang terkait dengan "penjualan" komponen EVA, proses manajemen manufaktur yang terkait dengan Komponen "biaya operasional", praktik manajemen keuangan yang terkait dengan Komponen "biaya keuangan", praktik manajemen peralatan produksi terkait untuk "aset modal bersih", dan praktik manajemen modal kerja yang terkait dengan Komponen "aset lancar". Sistem EVA mirip dengan Balanced Scorecard, dalam hal itu harus disesuaikan dengan konteks perusahaan yang menggunakannya. Menurut Cocca and Alberti (2010), jika rasio kinerja keuangan berguna bagi UKM, maka harus memberikan manajemen dengan panduan tentang cara mengelola ketidakpastian, berinovasi dalam istilah produk dan layanan, dan mendukung pengembangan perusahaan. Gambar 1 menunjukkan bahwa rasio keuangan memungkinkan untuk mengidentifikasi jalur yang mengarah ke penciptaan nilai bagi perusahaan, sehingga memungkinkan manajer dan karyawan untuk memfokuskan energi pada praktik yang meningkatkan nilai dan baik meningkatkan atau membuang yang hancurkan nilai. Manfaat-manfaat ini disorot oleh Young and O'Byrne (2001) yang mencatat bahwa perusahaan yang menggunakan EVA cenderung menggunakan aset lebih efisien dan menghilangkan kegiatan yang tidak menguntungkan. Pada penelitian ini, perhitungan EVA pada sektor UMKM akan menggunakan konsep PMMS yang diusulkan oleh Hudson, et al (2001). EVA dapat berguna sebagai panduan kinerja alat, bukan hanya sebagai alat pengukuran, dikaitkan dengan indikator kegiatan yang menciptakan atau menghancurkan nilai dalam perusahaan. Bagian selanjutnya mengidentifikasi tautan potensial antara komponen EVA utama dan bisnis yang relevan praktik. 


\subsection{Human Capital dan Resouce-Based View}

Perusahaan memiliki sumber daya yang beraneka ragam perusahaan akan memperoleh keuntungan berdasarkan sumber daya yang langka. Dalam konsep RBV yang menjadi fokus perhatian adalah masalah sumber daya internal yang terdiri dari; (1) Sumber daya fisik , meliputi semua pabrik, peralatan, lokasi, teknologi dan bahan baku; (2) Sumber daya manusia, meliputi seluruh pegawai, berikut pelatihan, pengalaman, kepandaian, pengetahuan, keterampilan; (3) Sumber daya organisasi meliputi struktur perusahaan, proses perencanaan, sistem informasi, hak paten, merk dagang, hak cipta, database, dan sebagainya (Barney, 1991).

Modal Manusia / Human Capital dianggap sebagai komponen di antara yang lain dari modal intelektual, namun HC diakui oleh beberapa penulis sebagai sumber daya tak berwujud yang paling penting (Johanson 2015). Fornell (2000) berpendapat bahwa HC adalah kekuatan yang

memandu dua komponen lainnya dari IC, yaitu, modal relasional dan modal sosial. Selain itu, pengembangan modal struktural adalah dikondisikan oleh keberadaan HC. Selain itu, studi yang telah berurusan dengan interaksi antara unsur-unsur IC telah membuktikan supremasi HC. Bontis et.,al (2000) menegaskan bahwa HC secara positif mempengaruhi modal struktural perusahaan. Moon and Kym (2006) dan Hsu and Fang (2008) telah menyetujui peran positif HC dalam pengembangan komponen IC lainnya.

Modal intelektual / Intelectual Capital (IC) menjadi perhatian penting dalam beberapa tahun terakhir (Miles et al., 1998).IC terkait dengan tiga hal yakni modal manusia, modal relasional, dan modal struktural (Stewart, 1998; Sullivan, 1999; Kaufmann and Schneider, 2004; Boedker et al., 2005; Marr and Roos, 2005). Penelitian tersebut menganggap bahwa IC terkait erat dengan RBV karena dianggap sebagai sumber potensial keunggulan kompetitif bagi perusahaan Penelitian terhadap variabel Human Capital menemukan bahwa perbedaan diantara individu ditentukan oleh KSAO (Knowledge, Skills, abilities and other characteristics) (Ployhart, 2011). Menurut Gerhart dan Wright (2006), "knowlegde" adalah faktual atau informasi procedural diperlukan untuk melakukan tugas tertentu dan merupakan dasar keterampilan dan kemampuan yang dikembangkan; "Skills" mengacu pada tingkat kemampuan individu untuk melakukan tugas tertentu; "abilities" berhubungan lebih umum dengan kapasitas yang diperlukan bagi seorang individu untuk melaksanakan tugas terkait dengan suatu fungsi; Akhirnya, "other characteristics" sering merujuk pada ciri kepribadian atau atribut lainnya yang memengaruhi kemampuan individu untuk melakukan tugas tertentu (Ployhart et al., 2011).

Dengan demikian, individu seharusnya memiliki kemampuan yang heterogen berdasarkan KSAO yang umumnya stabil dan memiliki asal intra-psikis. Para peneliti mengidentifikasi bagaimana KSAO ini memengaruhi produktivitas Schmidt and Hunter, 1998).

\subsection{Pengaruh Human Capital terhadap Penciptaan Nilai.}

Penelitian dari Oppong et al. (2019) meneliti data pada 33 perusahaan asuransi di Ghana dari 2008 hingga 2016 untuk mengukur modal intelektual dan pengaruh komponennya terhadap kinerja perusahaan. Penelitian tersebut mengungkapkan bahwa efisiensi sumber daya manusia berpengaruh signifikan terhadap produktivitas perusahaan asuransi. Selain itu, Ulum et al. (2019) mengungkapkan bahwa human capital telah menunjukkan hubungan yang positif dengan minat mahasiswa baru di masa depan.

Penelitian dari Smriti and Das (2018) meneliti dampak modal intelektual terhadap kinerja keuangan pada 710 perusahaan India dari 2001 hingga 2016. Hasilnya menunjukkan bahwa efisiensi modal yang digunakan dan efisiensi modal struktural 
merupakan kontributor yang sama pentingnya bagi perusahaan, sedangkan efisiensi modal manusia memiliki dampak yang besar. pada produktivitas perusahaan.

Penelitian dari Hoang et al. (2018) melakukan survei terhadap 319 perusahaan teknologi informasi di Vietnam untuk mengukur pengaruh modal intelektual (termasuk modal manusia, modal sosial, modal organisasi) terhadap kinerja perusahaan. Berdasarkan analisis faktor eksplorasi, analisis faktor konfirmatori, dan analisis moderasi, penelitian ini menyimpulkan bahwa modal manusia dan modal sosial sangat terkait dengan kinerja perusahaan.

Penelitian dari Buallay (2017) meneliti hubungan antara komponen modal intelektual (efisiensi modal manusia, efisiensi modal struktural, dan efisiensi penggunaan modal) dan tiga indikator yang mewakili kinerja perusahaan (termasuk return on asset [ROA], return on equity [ROE] , dan Tobin's Q) dari 171 perusahaan yang terdaftar di bursa Saudi dari tahun 2012 hingga 2014. Hasil penelitian menunjukkan bahwa efisiensi sumber daya manusia berpengaruh positif signifikan terhadap ROE. Demikian pula, Rahim et al. (2017) mempelajari 55 perusahaan teknologi Malaysia pada tahun 2009. Hasil penelitian menunjukkan bahwa efisiensi modal manusia memiliki hubungan yang signifikan dan positif dengan kinerja perusahaan.

Penelitian dari Kwarbai and Akinpelu (2016) menggunakan model regresi linier berganda untuk menganalisis pengaruh efisiensi modal manusia terhadap kinerja perusahaan pada perusahaan barang industri yang terdaftar di Bursa Efek Nigeria dari tahun 2009 hingga 2014. Penelitian ini menemukan bahwa efisiensi modal manusia memiliki hubungan yang signifikan positif dengan ROA dan laba per saham, dan efisiensi modal manusia tertinggal memiliki hubungan negatif dengan pertumbuhan jumlah karyawan.

Penelitian dari Parham dan Heling (2015) mengumpulkan data pada 33 perusahaan produksi Belanda dari tahun 2007 hingga 2012 untuk mengukur pengaruh efisiensi modal manusia terhadap kinerja perusahaan. Temuan penelitian ini menunjukkan hubungan positif antara efisiensi sumber daya manusia dan ketiga ukuran kinerja perusahaan (ROA, ROE, dan produktivitas karyawan).

Kendala terbesar dalam penelitian dari dampak human capital terhadap penciptaan nilai adalah tidak ada metode universal yang digunakan untuk menilai modal manusia dalam bentuk angka maupun grafik (Česynienè and Stankevičienė; 2011). Penelitian dari Beattie and Smith (2010) berpendapat bahwa beberapa penelitian melaporkan efektivitas investasi dalam sumber daya manusia untuk keunggulan kompetitif organisasi. Guthrie and Petty (2007) dalam studi empirisnya, menyoroti enam komponen modal manusia: knowhow, pendidikan, keterampilan kerja, pengetahuan terkait pekerjaan, keterampilan profesional dan kewirausahaan. Tujuannya adalah untuk menjelaskan apakah komponenkomponen ini dianggap sebagai anteseden penciptaan nila dan apakah komponen tersebut tercermin dalam laporan tahunan perusahaan Australia. Penelitian Brennan (2001) dan Bozzolan (2008) menganalisis komponen yang sama di 11 perusahaan Irlandia dan 30 perusahaan Italia. Beattie and Smith (2010) melakukan studi empiris tentang kontribusi modal manusia terhadap penciptaan nilai dengan melakukan analisis komparatif dari peran modal manusia dalam menghasilkan nilai perusahaan menurut 160 manajer fungsional: 67 direktur sumber daya manusia dan 93 direktur keuangan.

Hasil penelitian terdahulu dari Ifleh et al., (2018) menemukan hasil berbeda bahwa HC berpengaruh negative signifikan terhadap penciptaan nilai dengan melibatkan 31 direktur hotel di Maroko. Hasil penelitian ini mengidentifikasi bahwa ukuran kinerja operasional lebih didominasi oleh sumber daya manusia daripada keseluruhan ukuran kinerja yang diukur dengan EVA. Berdasarkan hasil penelitian terdahulu tersebut maka 
kesimpulan sementara atau hipotesis yang diajukan dalam penelitian ini dapat Human Capital berpengaruh positif terhadap Penciptaan Nilai pada sektor UMKM di Provinsi Bali.

\section{METODE PENELITIAN}

\subsection{Metode Pengumpulan Data}

Metode pengumpulan data penelitian ini menggunakan kuisioner, wawancara mendalam dan studi observasi lapangan. Kuisioner yang digunakan dalam penelitian mengadopsi dari Taylor et al (2006). Wawancara mendalam dilakukan secara tidak terstruktur, lentur dalam suasana informal, dan dilakukan secara berulang. Tujuannya adalag untuk menggali informasi secara jujur terkait dengan fenomena-fenomena UMKM, sehingga diperoleh informasi sebenarnya. Wawancara mendalam ini dilakukan sejak survey awal untuk menganalisis fenomena, variabel laten dan indikator penelitian. Studi observasi lapangan yang dikumpulkan untuk studi kasus mengenai segala hal yang berkaitan dengan dokumen administratif UMKM mengenai buku catatan kas masuk, kas keluar, nota-nota dan dokumen pendukung lainnya. Dokumen-dokumen yang dibutuhkan dan digunakan dalam penelitian ini meliputi laporan keuangan UMKM tahun 2016-2018, arsip-arsip dan buku besar.

\subsection{Populasi dan Sampel Penelitian}

Populasi dan Sampel Penelitian Populasi dalam penelitian ini adalah UMKM yang berada dalam pembinaan Dinas Koperasi dan UKM Provinsi Bali melalui program Program Kegiatan. Peningkatan Akses Pembiayaan UMKM Provinsi Bali pada tahun anggaran 2019 sebanyak 450 unit yang tersebar di 9 kabupaten/kota se Provinsi Bali. Teknik pengambilan sampel dalam penelitian ini adalah metode Proportionate Stratified Random Sampling. Teknik ini umumnya digunakan pada populasi yang bersifat heterogen (Sugiyono, 2008). Sampel diambil dari setiap strata berdasarkan jenis usahanya kemudian secara proporsional diambil besarannya sehingga diperoleh sampel untuk penelitian. Pengambilan sampel dilakukan melalui dua tahap. Pertama, responden yang dipilih adalah berasal dari UMKM sektor riil. Tahap kedua adalah responden yang dipilih merupakan sudah terdaftar sebagai wajib pajak. Ukuran sampel yang digunakan dalam penelitian dalam penelitian ini menggunakan rumus Slovin (Rahyuda, et.al. 2004) dengan formula sebagai berikut:

$$
N=\frac{N}{1+N e^{2}}
$$

Keterangan:

$\mathrm{n}=$ ukuran sampel

$\mathrm{N}=$ ukuran populasi

$\mathrm{e}=$ nilai kritis (batas ketelitian)

Berdasarkan rumus Slovin nilai kritis (e) yang digunakan sebesar 5 persen sehingga jumlah sampel $(n)$ dalam penelitian ini adalah:

$$
\begin{gathered}
N=\frac{N}{1+N e^{2}} \\
N=\frac{450}{1+(450)(5 \%)^{2}} \\
N=\frac{450}{1+(450)(0,05)^{2}} \\
N=211,76
\end{gathered}
$$


Hasil perhitungan menunjukan bahwa jumlah sampel adalah sebanyak 211,76 atau dibulatkan menjadi 212 sampel.

\subsection{Definisi Operasional}

Definisi operasional variabel penelitian adalah sebagai berikut:

1) Human Capital adalah sumber daya manusia yang diukur dari perbedaan diantara individu ditentukan oleh KSAO (Knowledge, Skills, abilities and other characteristics) pada pelaku UMKM di Provinsi Bali. Indikator pengukuran dari Human Capital adalah sebagai berikut (Subramaniam and Youndt, 2005):

a. Karyawan memiliki keterampilan.

b. Karyawan memiliki kemampuan yang terbaik di industri.

c. Karyawan memiliki kecerdasan dan kreatifitas.

d. Karyawan memiliki keahlian khusus dalam bidangnya.

e. Karyawan memiliki kemampuan dalam mengembangkan ide dan pengetahuan yang baru.

2) Economi Value Added merupakan pengukuran kinerja usaha kecil menengah Provinsi Bali dalam usahanya menciptakan nilai perusahaan. Perusahaan dinyatakan baik apabila nilai EVA positif, karena mampu menciptakan nilai ekonomis. Sebaliknya, apabila nilai EVA negatif maka kinerja perusahaan tidak baik karena tidak mampu menciptakan nilai ekonomis. Pengukuran EVA dalam penelitian ini akan menggunakan metode dari Hudson, et al (2001) dengan formula sebagai berikut:

$$
E V A=\text { NOPAT }-(\text { Cost of Capital }- \text { Invested Capital })
$$

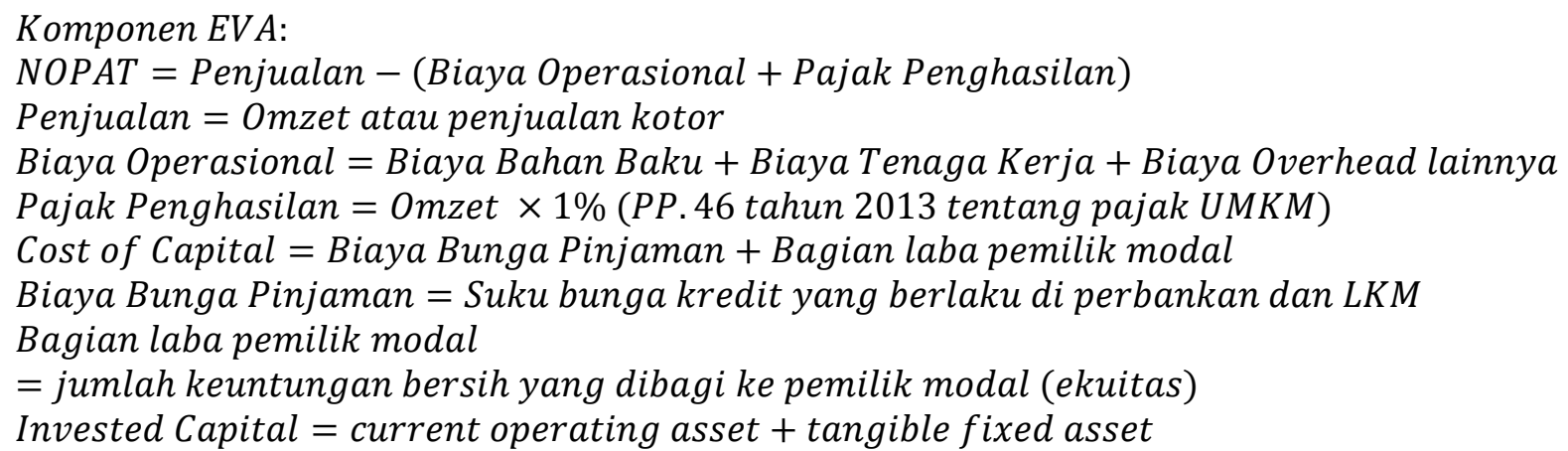

\subsection{Metode Analisis}

Penelitian ini menggunakan analisis regresi. Analisis regresi digunakan untuk melakukan regresi pada hubungan antara variable bebas terhadap variable terikat, untuk menentukan pengaruh antara human capital terhadap penciptaan nilai perusahaan melalui perhitungan EVA pada pelaku UMKM di Provinsi Bali.

\section{PEMBAHASAN}

Variabel kinerja keuangan dalam penelitian ini menggunakan metode pengukuran Economic Value Added (EVA) yang diadopsi dari Hudson, et al (2001) dengan menghitung komponen nilai rata- rata laporan keuangan selama periode tahun 2016-2018. EVA mengukur nilai tambah ekonomis yang diciptakan oleh UMKM dalam satu periode. Konsep dasarnya adalah laba operasi bersih setelah pajak (NOPAT) perusahaan dikurangi biaya modal yang digunakan untuk menghasilkan laba itu, yaitu biaya tingkat modal (Cost 
of Capital/CoC) dikalikan dengan modal yang diinvestasikan (Invested Capital/IC). Hasil perhitungan akan menyatakan bahwa UMKM yang baik apabila nilai EVA positif, karena mampu menciptakan nilai ekonomis. Sebaliknya, apabila nilai EVA negatif maka kinerja perusahaan tidak baik karena tidak mampu menciptakan nilai ekonomis. Berdasarkan Hasil perhitungan EVA ditampilkan pada Tabel dibawah ini.

Tabel 1

Jumlah UMKM Berdasarkan Kinerja Kuangan (Rasio EVA)

\begin{tabular}{ccc}
\hline Keterangan & \multicolumn{2}{c}{ Skala Nilai EVA } \\
\cline { 2 - 3 } & EVA positif & EVA negative \\
\hline Jumlah UMKM & 71 & 141 \\
\hline Rata-Rata nilai EVA & \multicolumn{3}{c}{-Rp. 32.815.499.- } \\
\hline Sumber: Data Primer, diolah (2020) & \multicolumn{2}{l}{}
\end{tabular}

Tahap selanjutnya dilakukan pengujian terhadap kesesuaian model melalui berbagai. Convergent validity korelasi antara skor indikator refleksif dengan skor variabel latennya. Penelitian ini menggunakan loading factor 0,5 sampe dengan 0,6 dianggap cukup, karena merupakan tahap awal pengembangan skala pengukuran dan jumlah indikator per konstruk tidak besar yaitu berkisar antara tiga sampai dengan tujuh indikator. Berdasarkan hasil pengolahan data bahwa indikator dari variabel Human Capital dalam penelitian ini memiliki loading factor diatas 0,5. Nilai AVE dalam persamaan ini diperoleh nilai diatas 0,50 maka model dalam penelitian ini memiliki korelasi antar konstruk yang baik. Pada penelitian ini memiliki nilai Cronbach alpha dan composite reliability diatas 0,70 maka kelompok indikator yang mengukur variabel dalam penelitian ini memiliki reliabilitas komposit yang baik.

Hipotesis diuji dengan uji t (t-test). Apabila dalam pengujian diperoleh p-value 0,05 $(\alpha=5 \%)$, maka pengujian signifikan, hasil nalisis direct effect diiktisar nilai-nilai estimasi parameter beserta nilai critical ratio dari model struktural tersaji pada Tabel 2.

\begin{tabular}{|l|c|c|c|c|c|}
\hline & $\begin{array}{c}\text { Original } \\
\text { Sample (O) }\end{array}$ & $\begin{array}{c}\text { Sample } \\
\text { Mean (M) }\end{array}$ & $\begin{array}{c}\text { Standard } \\
\text { Deviation } \\
(\text { STDEV })\end{array}$ & $\begin{array}{c}\text { T Statistics } \\
(\mid \mathrm{O} / \text { STDEV } \mid)\end{array}$ & P Values \\
\hline $\begin{array}{l}\text { Human } \\
\text { Capital }(\mathrm{X})-> \\
\text { EVA (Y) }\end{array}$ & 0.622 & 0.645 & 0.266 & 2.343 & 0.020 \\
\hline
\end{tabular}

$$
\begin{aligned}
& Y=0,622 X+e \\
& p-\text { value }=0,020 \\
& t-\text { hitung }=2.343
\end{aligned}
$$

Berdasarkan Tabel 2 diketahui bahwa hasil estimasi parameter model menunjukan nilai estimasi human capital terhadap economic value added sebesar 0,$622 ; p$ value sebesar 0,020; berdasarkan koefisien original sample yang mengukur pengaruh human capital terhadap economic value added maka dapat dinyatakan bahwa hipotesis dalam penelitian diterima.

Hasil tersebut menunjukan bahwa kualitas human capital berpengaruh terhadap kinerja keuangan yang diukur dengan penciptaan nilai tambah ekonomi (EVA) UMKM di Provinsi Bali. Hasil penelitian ini mengkonfirmasi bahwa efektivitas investasi dalam sumber daya manusia dapat menciptakan keunggulan kompetitif organisasi. Komponen 
human capital seperti Knowhow, pendidikan, keterampilan kerja, pengetahuan terkait pekerjaan, keterampilan profesional dan kewirausahaan dapat berpotensi sebagai antesedem dalam penciptaan nilai perusahaan dan akan tercermin dalam kinerja keuangan dan keberlangsungan dari sektor UMKM itu sendiri. Penelitian ini mengkonfirmasi penelitian dari Česynienè and Stankevičienè (2011); Beattie and Smith (2010); Guthrie and Petty (2007); Brennan (2001) dan Bozzolan (2008); Oppong et al. (2019); Smriti and Das (2018); Hoang et al. (2018); Rahim et al. (2017); Kwarbai and Akinpelu (2016); Parham dan Heling (2015).

Hasil penelitian ini mengkonfirmasi bahwa kualitas UMKM sangat ditentukan oleh keunggulan kompetitif dengan memanfaatkan sumber daya yang memfokuskan pada pengembangan atau perolehan sumber daya (resource) dan kapabilitas (abilities) yang berharga. Kombinasi unsur antara aset real sepeti sumber daya financial dan aset yang tidak terlihat (intangible asset) salah satunya pengetahuan dan pengalaman dapat diintegrasikan dalam mencapai tujuan yang diinginkan untuk mencapai daya saing untuk memperoleh keuntungan dan mencapai keunggulan kompetitif disaat mampu menciptakan nilai tambah dengan mengeksploitasi sumber daya untuk menghasilkan keunggulan kompetitif. Hasil penelitian ini mengkonfirmasi hasil penelitian dari Yuliana dan Khoiriyah (2018) menunjukkan bahwa terdapat pengaruh positif dan signifikan Modal Intelektual terhadap Keunggulan Kompetitif, Modal Intelektual terhadap Kinerja Keuangan, dan Keunggulan Kompetitif mampu memediasi pengaruh Modal Intelektual terhadap Kinerja Keuangan

Hasil penelitian ini juga mengkonfirmasi bahwa perhitungan EVA berdasarkan konsep Hudson et al, (2001) dapat berfungsi dengan baik pada sektor UMKM, hasil penelitian ini mempertegas bahwa EVA bisa digunakan dengan baik pada perusahaan kecil dan menengah, dan berfungsi dengan baik seperti pada perusahaan yang sudah go public.

\section{KESIMPULAN}

Berdasarkan hasil penelitian dapat disimpulkan bahwa pengaruh Human Capital positif signifikan terhadap pencapaian nilai tambah ekonomi (EVA) UMKM di Provinsi Bali. Hasil penelitian ini mengkonfirmasi bahwa efektivitas investasi dalam sumber daya manusia dapat menciptakan keunggulan kompetitif organisasi. Komponen human capital seperti Knowhow, pendidikan, keterampilan kerja, pengetahuan terkait pekerjaan, keterampilan profesional dan kewirausahaan dapat berpotensi sebagai antesedem dalam penciptaan nilai perusahaan.

Implikasi teoritis dalam penelitian ini adalah keberhasilan dalam menguji pengaruh human capital terhadap EVA pada sektor UMKM. Selain itu, penelitian ini mengkonfirmasi bahwa perhitungan EVA dapat dengan baik dilakukan pada sektor UMKM, apabila dibandingkan pada penelitian sebelumnya penggunaan EVA hanya sebatas pada perusahaan yang sudah go public.

Implikasi praktis dalam penelitian ini adalah meningkatkan intangible asset pada sektor UMKM melalui pendampingan teknis manajerial dalam pembuatan anggaran tahunan, pembuatan laporan keuangan yang sesuai dengan standar (SAK ETAP), memberikan kesempatan akses modal kepada pelaku UMKM serta meningkatkan pelayanan konsultasi untuk UMKM yang akan memperluas perdagangan ekspor ke luar negeri melalui Dinas Koperasi dan UKM di provinsi dan kabupaten/kota

Keterbatasan dalam penelitian ini adalah penggunaan laporan keuangan UMKM yang tidak seluruhnya lengkap dan sesuai standar. 


\section{DAFTAR PUSTAKA}

Al-Musali, M. A. K., \& Ismail, K. N. I. K. (2014). Intellectual capital and its effect on financial performance of banks: Evidence from Saudi Arabia. Procedia - Social and Behavioral Sciences, 164, 201-207. https://doi.org/10.1016/j.sbspro.2014.11.068. [Crossref], [Google Scholar].

Barney, J.B., \& Arikan, A. M. 2001. The Resource-based view: origin and implication. The Blackwell handbook of strategic management.

Boedker, C., Guthrie, J., \& Cuganesan, S. (2005). An integrated framework for visualising intellectual capital. Journal of Intellectual Capital, 6(4), 510-527.

Boselie, P., Dietz, G. dan Boon, C. 2005. Commonalities and contradictions in HRM and performance research. Human Resource Management Journal, 15(3): 67-94. Available from:

URL: https://www.researchgate.net/publication/261215048_boselie_dietz_boon_2005

Bontis, N. 2002. National intellectual capital index: Intellectual capital development in the Arab Region. Ontario: Institute for Intellectual Capital Research.

Bozzolan, S., F. Favotto, and F. Ricceri. 2003. Italian annual intellectual capital disclosure; An empirical analysis. Journal of Intellectual Capital. Vol. 4 No.4. pp. 543-558.

Brennan, N. 2001. Reporting intellectual capital in annual reports: evidence from Ireland. Accounting, Auditing \& Accountability Journal. Vol. 14 No. 4. pp. 423-436.

Buallay, A. M. (2017). The relationship between intellectual capital and firm performance. Corporate Governance and Organizational Behavior Review, 1(1), 32 41. https:// doi.org/10.22495/cgobr [Crossref], [Google Scholar]

Cocca, P. and Alberti, M. 2010. A framework to assess performance measurement systems in SMEs. International Journal of Productivity and Performance Management, 59 (2), pp. 186-200. Available from: URL: https://www.emeraldinsight.com/doi/full/10.1108/17410401011014258?mobileU $\underline{i=0 \& f u l l S c}=1 \& m b S_{c}=1 \&$ fullS $c=1 \& f u l l S_{c}=1$

Dilon, R. 1997. Eva as a financial metric: Atrributes, utilization, and relationship. Practice $\mathcal{E}$ Education 7 1-10.

Fornell, C. 2000. Customer asset management, capital efficiency, and shareholder value: performance measurement, past, present and future. Conference at the University of Cambridge,

Garengo, P., Biazzo, S. and Bititci, U.S. 2005. Performance measurement systems in SMEs: a review for a research agenda. International Journal of Management Reviews, 7 (1), 25-47. Available from: URL: https://onlinelibrary.wiley.com/doi/abs/10.1111/j.1468-2370.2005.00105.x 
Guthrie, J., dan R. Petty. 2000. Intellectual Capital: Australian Annual Reporting Practices. Journal of Intellectual Capital, Vol. 1, No. 3, p. 241-251.

Hoang, T. N., Thong, B. Q., \& Phuong, N. 2018. The impact of intellectual capital dimensions on Vietnamese information communication technology firm performance: A mediation analysis of human and social capital. Academy of Strategic Management Journal, 17(1), 1-15. [Google Scholar]

Hsu Y-H., Fang W., 2009. Intellectual capital and new product development performance : the mediating role of organiziational learning capability. Technological Forecasting And Social Change.

Hudson, M., Smart, A. dan Bourne, M. 2001. Theory and practice in SME performance measurement systems. International Journal of Operations \& Production Management, 21 (8), 1096-115. Available from: URL: https://pdfs.semanticscholar.org/b9ea/34b0b759447a71bcea83bfd5a6c4c23dac83. pdf

Ifleh, Ypussef., Lotfi, Mohamed.,dan Elkabbouri, Mounime. 2018. Rethinking Value Creation From The Resource Based View: The Case of Human Capital in Moroccan Hotels. International Journal of Applied Management and Economics.

Johanson, U. 2005. A human resource perspective on intellectual capital. In B. Marr (Ed.), Perspective on intellectual capital. Multidisciplinary insights into management, measurement and reporting. Boston: Elsevier

Kaufmann, L., \& Schneider, Y. 2004. Intangibles: a synthesis of current research. Journal of Intellectual Capital, 5(3), 366-388.

Kwarbai, J. D., \& Akinpelu, M. A. 2016. Human capital efficiency and corporate performance: The Nigerian perspective. International Journal of Business and Management,4(3). https:// papers.ssrn.com/sol3/papers.cfm?Abstract_id=2765863 [Google Scholar]

Marr, B., \& Roos, G. 2005. A Strategy perspective on intellectual capital. In B. Marr (Ed.), Perspective on intellectual capital. Multidisciplinary insights into management, measurement and reporting. Boston: Elsevier.

Miles, G., Miles, R. E., Perrone, V., \& Edvinsson, L. 1998. Some conceptual and research barriers to the utilization of knowledge. California Management Review, 40(3), 281-288.

Mondal, A., \& Ghosh, S. K. (2012). Intellectual capital and financial performance of Indian banks. Journal of Intellectual Capital, 13(4), 515530. https:// doi.org/10.1108/14691931211276115 [Crossref], [Google Scholar]

Moon Y.J., Kym H.G., 2006. A model for the value of intellectual capital. Canadian journal of administrative science. 
Oppong, G., Pattanayak, J., \& Irfan, M. (2019). Impact of intellectual capital on productivity of insurance companies in Ghana. Journal of Intellectual Capital, 20(6), 763-783. https://doi.org/10.1108/JIC-12-2018-0220 [Crossref], [Web of Science ${ }^{\circledR}$ ], [Google Scholar]

Ozkan, N., Cakan, S., \& Kayacan, M. 2017. Intellectual capital and financial performance: A study of the Turkish banking sector. Borsa Istanbul Review, 17(3), 190-198. https://doi.org/10.1016/j.bir.2016.03.001. [Crossref], [Web of Science ®], [Google Scholar].

Parham, S., \& Heling, G. W. J. 2015. The relationship between human capital efficiency and financial performance of Dutch production companies. Research Journal of Finance and Accounting, 6(8), 188-201. [Google Scholar]

Poh, L. T., Kilicman, A., Ibrahim, S. N. I., \& McMillan, D. 2018. On intellectual capital and financial performances of banks in Malaysia. Cogent Economics $\mathcal{E}$ Finance, 6(1), 1453574. https://doi.org/10.1080/23322039.2018.1453574 [Taylor \& Francis Online], [Web of Science ${ }^{\circledR}$ ], [Google Scholar].

Rahim, A., Atan, R., Kamaluddin, A., Jaaffar, M.

Y., Abdullah

Sani, A., \& Muhammad, A. (2017). Human capital efficiency and firm performance: An empirical study on Malaysian technology industry. SHS Web of Conferences, 36, 00026. https://doi.org/10.1051/shsconf/20173600026 [Crossref], [Google Scholar]

Sardo, F., \& Serrasqueiro, Z. (2017). A European empirical study of the relationship between firms' intellectual capital, financial performance and market value. Journal of Intellectual Capital, 18(4), 771-788. https://doi.org/10.1108/JIC-10-2016-0105 [Crossref], [Web of Science ${ }^{\circledR}$ ], [Google Scholar].

Smriti, N., \& Das, N. (2018). The impact of intellectual capital on firm performance: A study of Indian firms listed in COSPI. Journal of Intellectual Capital, 19(5), 935-964. https://doi.org/10.1108/jic-11-2017-0156 [Crossref], [Web of Science ®], [Google Scholar].

Stern, J. dan Shiely, J. 2000. El reto el EVA. Spain. Gestión.

Stewart. 1990. The Quest for Value. USA: Harper Business.

Subramaniam, M., \& Venkatraman, N. 2001. Determinants of transnational new product development capability: Testing the influence of transferring and deploying tacit overseas knowledge. Strategic Management Journal, 22: 359-378.

Sullivan, P. H. 2005. An intellectual property perspective on intellectual capital. In B. En Marr (Ed.), Perspective on intellectual capital. Multidisciplinary insights into management, measurement and reporting. Boston: Elsevier.

Tran, D. B., \& Vo, D. H. (2018). Should bankers be concerned with intellectual capital? A study of the thai banking sector. Journal of Intellectual Capital, 19(5), 897-914. 
https://doi.org/10.1108/JIC-12-2017-0185 [Crossref], [Web of Science ®], [Google Scholar].

Ulum, I., Harviana, R. R., Zubaidah, S., \& Jati, A. W. 2019. Intellectual capital disclosure and prospective student interest: An Indonesian perspectives. Cogent Business $\mathcal{E}$ Management, 6(1), 1707041. https://doi.org/10.1080/23311975.2019.1707041 [Taylor \& Francis Online], [Web of Science ${ }^{\circledR}$ ], [Google Scholar].

Yuliana, Indah., Khoiriyah, Jam'iyyatul. 2018. Modal Intelektual, Keunggulan Kompetitif, dan Kinerja Keuangan Pada Perusahaan High Ic di Indonesia dan Singapura. JMM UNRAM, 7(4), 17 - 32 